\title{
TRANSLATING PERCEPTION METAPHORS. A PROCESS-BASED APPROACH
}

\author{
Anu Kalda \\ Tallinn University
}

\begin{abstract}
The article describes the results of a context-based translation task on translating English perception metaphors into Estonian. Empirical research was carried out with 21 professional translators who were all native Estonians. The analysis is based on a sequence of translation strategies and the frequency of their usage as well as on the data collected on consulting online sources during the translation task. The research showed that the majority of perception metaphors are preserved in the target texts. Data suggest that the cognitive load of perception metaphors seems to be higher than of other linguistic forms, especially that of colour metaphors. ${ }^{1}$
\end{abstract}

Keywords: metaphor translation, cross-cultural metaphors, culture-specific metaphors, translation strategies, translation process, digital resources, translation aids, cognitive linguistics, Estonian, English

\section{Introduction}

In this article, the main research focus is on how perception metaphors are translated, i.e. what strategies are chosen while translating. The hypothesis was that perception metaphors can be challenging to translate and demand more effort from the translator during the translation process, meaning that they have higher cognitive load than other linguistic forms. The second area of interest focuses on the online sources translators use while translating perception

\footnotetext{
1 This research was supported by Tallinn University, School of Humanities, grant number TF3717 “Translating perception metaphors".
} 
metaphors. The prediction was that perception metaphors in translated texts entail a greater need to consult online sources compared to other linguistic forms.

Lakoff and Johnson (1980) suggest that metaphors not only affect how people communicate ideas, but actually structure perceptions and understanding about the world. They believe that the way we use metaphors reveals how we perceive the world and consequently the culture in which we live. Some metaphors are shared across languages and cultures, while others are limited to the society in which they are used. Such culture-specific metaphors can become challenging to translators who wish to remain true to the source text without compromising the genuineness of target text (see Schäffner 2004 for further discussion on metaphor transferability). Besides cultural aspects, modern metaphor theory also underlines the usefulness of the context (Glucksberg 2003, Kövecses 2015). Context can help a reader to comprehend an unfamiliar metaphor in a text, although there is evidence of the contrary, i.e. when context is misleading (Kalda, Uusküla 2019: 697). It has been argued that figurative expressions such as metaphors become salient (cognitively prominent) when encountered in another language, thus attracting cognitive attention due to their novelty (Johanson 2002: 309, Verschik 2019: 72). This suggests that metaphors demand more effort on the part of the translator during the translation process. Perception metaphors in particular have recently come to prominence in cognitive linguistics. Ibarretxe-Antuaño (2019: 60) claims that all languages have perception metaphors, but stresses that perception metaphors differ in terms of their distribution, motivation, and the linguistic means employed to systemize their metaphoric expressions. Therefore, it becomes especially interesting to investigate the translating of perception metaphors. Within this article a perception metaphor is a metaphor that contains a perception word (colour, smell, taste or temperature word).

Metaphor can also be considered as a metaphor for translation itself (Lange 2008: 44). First, one has to translate the metaphor in 
the source language in order to uncover its meaning. Only then, it is possible to translate it into the target language. Therefore, metaphor translation implies double translation. Metaphor translation has been extensively researched (van den Broeck 1981; Newmark 1988; Toury 1995; Vinay, Darbelnet 1995; Schäffner 2004; TirkkonenCondit 2011; Ervas, Gola 2017, amongst others).

The article researches metaphor translation in the framework of the recent shift in translation studies from text-based to processbased analysis (Ehrensberger-Dow 2018: 294-295). By analysing not only the results of translation process - target texts, but also the translation process itself, researchers are able to understand what influences the translation process and why. The methods that have been used in recent decades help us to get closer to an understanding of the actual translation process (via keystroke logging, eye-tracking, heart rate and blood pressure analysis, skin galvanic reactions, measuring brain activity, etc.). In the case of metaphor translation analysis, the combining of different methods is recommended (Schäffner, Shuttleworth 2013: 93). Sjørup (2008, 2013) used eye-tracking and keystroke logging to analyse the translating of English metaphors into Danish. Hvelplund (2017) used the same methods to analyse translators' use of digital resources during translation. These studies on translation process analysis inspired the design of the current study.

In Estonia, translation process analysis has to date received very little attention (Taukar et al. 2018: 198). Furthermore, there is also little evidence from empirical analysis on metaphor translation in Estonia. In addition to my previous study on colour metaphor translation (Kalda 2016), the translating of Spanish idioms (Saar 2014) and English emotion metaphors (Mõttus 2019) has been analysed empirically. My analysis aims at providing a small contribution to Estonian translation studies. It also encourages translators and translation students, as well as those interested in language or cultural studies, to pay attention to issues related to perception metaphors while translating. 
The structure of the article is as follows. First, I describe my methods, data collection principles and participants. Then the results of the empirical study follow together with a discussion illustrated by some of the most characteristic examples from the study. Finally, conclusions are presented.

\section{Method, materials and participants}

This article describes the results of an empirical study with focus on how professional translators translate perception metaphors in context. During the experiment, four texts were presented to the participants sequentially. The texts were generated by the author using English Corpora $\mathrm{iWeb}^{2}$ and contained 134-148 words. The sentences that contained the perception metaphors selected by the author were derived from the corpus, edited minimally and put together in order to ensure coherent context. There were altogether 43 perception metaphors in the texts that were analysed separately. There were 21 colour metaphors in the texts, 12 taste and smell metaphors and 10 metaphors with temperature words. The principle of choosing metaphors for the study was that there would be both metaphors that are conventional and lexicalised only in the source language (used in English-speaking culture, e.g. yellow-bellied person) as well as cross-cultural metaphors (commonly used in both the source and target languages, e.g. black market, hot as hell). The list of perception metaphors used in the study are presented in Table 1.

The experiments were carried out in the laboratory of the School of Digital Technologies of Tallinn University from February until June 2019. The data were extracted by using Mirametrix eye-tracker, Translog II keystroke logger and semi-structured retrospective interviews. During the experiments only the participant and the author were present in the laboratory.

2 https://www.english-corpora.org/iweb/ (15.05.2020). 
Table I. Perception metaphors used in translation task

\begin{tabular}{|l|l|}
\hline $\begin{array}{l}\text { Colour } \\
\text { metaphors }\end{array}$ & $\begin{array}{l}\text { red tape, catch somebody red-handed, purple prose, yellow-bellied } \\
\text { person, out of the blue, silver lining, awash under a brown tide, true } \\
\text { colours, with flying colours, black market, white lie, white magic, } \\
\text { blue in the face, grey area, golden opportunity, like a red rag to } \\
\text { a bull, give the green light, rose-coloured glasses, dark ages, born } \\
\text { with a silver spoon in the mouth, silver hair }\end{array}$ \\
\hline $\begin{array}{l}\text { Taste and smell } \\
\text { metaphors }\end{array}$ & $\begin{array}{l}\text { sweet sixteen, sweet dreams, bittersweet memories, sour- } \\
\text { tempered person, salty language, sharp smell, friendship soured, salt } \\
\text { of the earth, spicy novel, soft in the head, soft voice, juicy scandal }\end{array}$ \\
\hline $\begin{array}{l}\text { Temperature } \\
\text { metaphors }\end{array}$ & $\begin{array}{l}\text { chilly greeting, hot as hell, hot debate, the hottest war zone, out } \\
\text { in the cold, cold in the grave, cool friend, play it cool, a warm trail, } \\
\text { warm support }\end{array}$ \\
\hline
\end{tabular}

Participation in the experiment was confidential. No remuneration was provided for completion of the experiment. All of the participants signed a participation form. There was no time limit set. They were allowed to consult online sources in order to fulfil the task. The participants did not receive any specific information about the task before the actual beginning of the test.

After the translation task was completed, semi-structured retrospective interviews in Estonian followed. The aim of the interviews was twofold. Firstly, participants provided information about their social (gender, age, language proficiency and whether they had lived in a country where English is an official and/or de facto or majority language) and professional background (duration of translation experience, whether or not they had studied translation, what were their main translation fields). Information about living in an English-speaking country was collected in order to be able to analyse whether living in a source language environment had any effect on translating perception metaphors. Secondly, feedback about the translation task was collected.

In order to make conclusions about perception metaphor translation, the approach chosen was triangulation of data sources and results. The following research material was used for analysis: 1) Translog II keystroke logger data provided the target texts; 2) Mirametrix eye-tracker provided the video recordings in order to 
analyse the participants' consulting of online sources; 3 ) and semistructured retrospective interviews. Target texts, video recordings and eye-tracking data gave objective data and interviews provided added-value with subjective information on how the participants perceived the task. For descriptive analysis of the target texts the following sequence of translation strategies was adapted from my previous study on analysing colour metaphor translation (Kalda 2016):

- reproducing the perception metaphor in the target language with a perception word

- replacing the perception metaphor with a metaphor with no perception word

- paraphrasing the perception metaphor

- omission, if the translator decides to exclude the perception metaphor

- obvious mistranslation of perception metaphor (original meaning gets lost in translation)

The focus of the study was on qualitative analysis - how participants transfer cultural phenomena - metaphors from English into Estonian.

There were 21 participants in the study ( 19 women, 2 men), all native Estonian speakers. The age range was 29-69 years, with the average age of 42.2 years. The criterion for including participants in the study was a minimum of two years of translation experience. This varied from two years to 35 years amongst the participants, with an average of 11.5 years. English was their main working language. Fourteen out of the 21 participants had studied translation at university. Nine had lived in an English-speaking country for an average of 2 years and 8 months. These countries were the United States, the United Kingdom, Canada, Australia, India, and Ireland. 


\section{Results and discussion}

In this section the results of the research are described and discussed. First, the general data on translation strategies are presented after which the data on four metaphors are introduced in detail. The second part of the section outlines information about the participants' consulting of online resources during the translation task.

\section{I. OVERVIEW AND EXAMPLES OF TRANSLATION STRATEGIES} USED IN THE STUDY

The five strategies outlined in Section 2 were used to describe and discuss the results of perception metaphor translation. In half of the cases the perception metaphor was preserved in the translation (e.g. hot debate translated as tuline vaidlus, see Example (4) in this section). Approximately a fifth of translation equivalents provided by the participants contained a metaphor without a perception word (e.g. bittersweet memories were translated as nukrusevarjundiga mälestused 'memories with a shade of sadness', see Example (3)). The participants decided to paraphrase the perception metaphors in a quarter of cases (e.g. purple prose was translated as keeruliselt ja ilulevalt kirja pandud 'written in a complex and vaunting manner', see Example (1)). When a participant decided that the meaning of the source text could be conveyed without a perception metaphor or was unaware of the specific metaphor, it was omitted in the target text (see Example (2)). There was also evidence of obvious mistranslation of perception metaphors (see Examples (1) and (2) for discussion).

The results of the current study follow a similar pattern to my previous study of context-based colour metaphor translation (Kalda 2016). In more than two thirds of the cases the metaphor is preserved in the translation, either with or without the perception metaphor. A quarter of perception metaphors were paraphrased in the target text and cases of obvious mistranslation remain minimal. The frequency of translation strategies used in this study is summarised in Table 2. 
Table 2. Summary of translation strategies used in translation task

\begin{tabular}{|l|c|c|}
\hline \multirow{2}{*}{ Translation strategy } & \multicolumn{2}{c|}{ Frequency in translated texts } \\
\cline { 2 - 3 } & $\begin{array}{c}\text { Number of times } \\
\text { strategies used }\end{array}$ & $\begin{array}{c}\text { Share of total amount } \\
\text { of metaphors }\end{array}$ \\
\hline $\begin{array}{l}\text { reproducing the perception } \\
\text { metaphor in target language with } \\
\text { a perception word }\end{array}$ & 464 & $51 \%$ \\
\hline $\begin{array}{l}\text { replacing the perception metaphor } \\
\text { with a metaphor with no } \\
\text { perception word }\end{array}$ & 165 & $18 \%$ \\
\hline $\begin{array}{l}\text { paraphrasing the perception } \\
\text { metaphor }\end{array}$ & 236 & $26 \%$ \\
\hline omission of the metaphor & 23 & $3 \%$ \\
\hline $\begin{array}{l}\text { obvious mistranslation (original } \\
\text { meaning gets lost in translation) }\end{array}$ & 15 & $2 \%$ \\
\hline Total & 903 & $100 \%$ \\
\hline
\end{tabular}

It is important to illustrate the five translation strategies outlined in Section 2 and Table 2. In order to provide insight into some of the most characteristic cases of perception metaphor translation, there are four metaphors that will be discussed in more detail. The summary of translation techniques used while translating these metaphors is presented in Table 3.

The examples represent all three categories analysed in this research. Namely, perception metaphors that contain either a colour word, taste or smell word or a temperature word. The chosen examples represent metaphors that are culture-specific - commonly used only in the source language - as well as the cross-cultural perception metaphors. However, the emphasis will be on the former. Each of these will be described in more detail below.

\section{(1) Perception metaphor purple prose}

According to Urban Dictionary ${ }^{3}$, purple prose is 'a term used to describe literature where the writing is unnecessarily flowery; it means that the writer described the situation (or wrote the entire

3 https://www.urbandictionary.com/ (15.05.2020). 


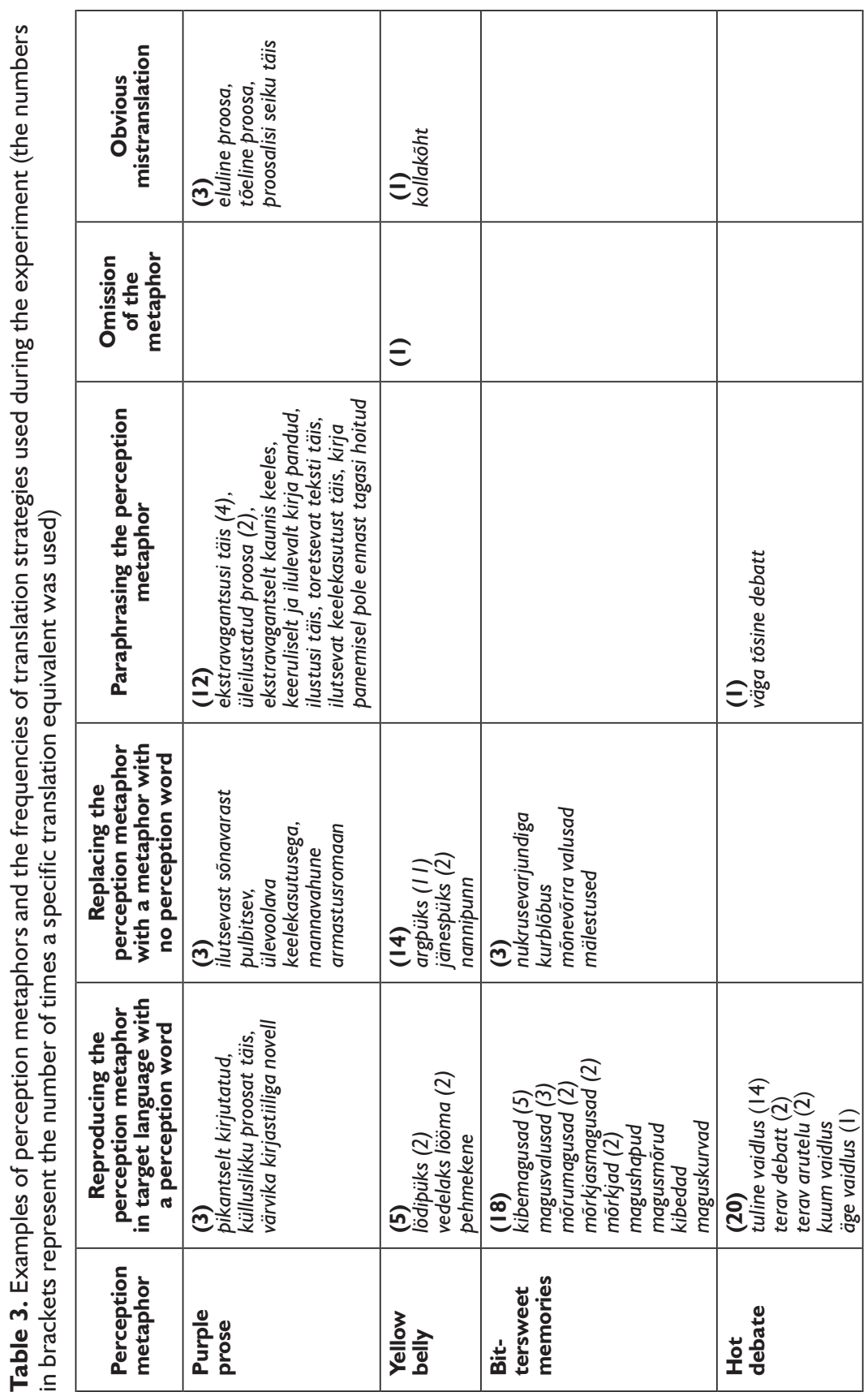


book, passage, etc.) using words that are too extravagant for the type of text, or any text at all, over-describing something with stupid words'. Another dictionary describes the metaphor as a writing that calls attention to itself because of its obvious use of certain effects, as exaggerated sentiment or pathos, especially in an attempt to enlist or manipulate the reader's sympathies (Collins Dictionary ${ }^{4}$ ). There is no similar commonly used perception metaphor in Estonian. Bilingual dictionaries provide a translation equivalent, üleilustatud proosa 'overly fancy prose'.

In this study, this was the metaphor with the largest number of different translation equivalents provided. The results can be divided between four groups of translation strategies.

- Three can be categorised as perception metaphors in the target texts:

pikantselt kirjutatud 'piquantly written'

külluslikku proosat täis 'full of lush prose'

värvika kirjastiiliga romaan 'novel written in colourful style'

- There are also three examples of metaphors without a perception word in the target text:

ilutsevast sõnavarast pulbitsev 'bubbling with fancy vocabulary' ülevoolava keelekasutusega 'with lavish language'

mannavahune armastusromaan 'romance novel like manna mousse'

- The majority of the participants decided to paraphrase the metaphor in the target text:

ekstravagantsusi täis (4) 'full of extravagance'

üleilustatud proosa (2) 'overly fancy prose'

ekstravagantselt kaunis keeles 'in a beautiful extravagant lan-

guage'

keeruliselt ja ilulevalt kirja pandud 'written in a complex and vaunting manner'

ilustusi täis 'full of embellishments'

4 https://www.collinsdictionary.com/ (15.05.2020). 
toretsevat teksti täis 'full of flamboyant text'

ilutsevat keelekasutust täis 'full of fancy language'

kirja panemisel pole ennast tagasi hoitud 'one has not held oneself back while writing it'

- Three translation equivalents can be described as mistranslations as they convey the opposite meaning to the original perception metaphor:

eluline proosa 'colloquial prose'

tõeline proosa 'true prose'

proosalisi seiku täis 'full of prosaic circumstances'

Colour metaphor purple prose proved to be challenging. This was the most frequently looked up metaphor by the participants. Fifteen out of the 21 participants consulted online sources while translating the metaphor (see Table 5 in Section 3.2). Video recordings and keystroke logging data reveal that translating this metaphor generated the largest amount of editing and deletion during the experiment. Purple prose was also the most frequently mentioned example of complicated parts of the text to translate when the participants were asked during the interviews to point out whether any particular phrase or part of the text was challenging to translate. One of the participants pointed out during the retrospective interview: 'I know what purple means and I know what prose is. However, it was a struggle to find a satisfactory translation equivalent. I derived it from the context.'

Despite the fact that the metaphor proved to be challenging and caused cases of mistranslation, the participants provided rather inventive translation equivalents. Especially noteworthy are pulbitsev 'bubbling', ülevoolav 'lavish', mannavahune 'like manna mousse'. They were categorised under the strategy of replacing the perception metaphor with a metaphor containing no perception word, although they induce perceptional associations (like the pink colour of the manna mousse can evoke similar associations to purple prose) as in this study the perception metaphor is defined by containing a colour, temperature or taste and smell word. 


\section{(2) Perception metaphor yellow belly}

English metaphor yellow belly is used when someone is said 'to be cowardly or easily scared. If you're yellow-bellied, you're not brave' (Vocabulary.com ${ }^{5}$ ). In Estonian there is no reference to a similar perception metaphor, at least not with a colour word.

- There were five perception metaphors in the translated texts:

lödipüks (2) a compound word of 'ooze' and 'pants'

ei löö vedelaks (2) will not chicken out, literally 'liquefy' pehmekene 'softie'

- The majority of the participants decided to preserve a metaphor in the target text without a perception word:

argpüks (11) 'cowardly', a compound word of arg 'cowardly' and püks(id) 'pants'

jänespüks (2) 'rabbit pants' (a literal translation), referring to a chicken heart (a rabbit is associated with being a bit shy and cowardly by Estonians)

nannipunn 'ninny', referring to being weak or cowardly

- One participant decided to omit this metaphor in the target text.

- There was one case of obvious mistranslation that does not convey the original meaning presented in the source text:

kollakõht 'yellow belly' (a literal translation)

The last example represents the case of a literal translation that does not convey the original meaning and is considered a case of mistranslation. This was one of the few metaphors where mistranslation occurred. During the interview the participant explained that as his background and translation field are technical he was unaware of such a metaphor and context did not support comprehension. It should be emphasised here that the connotation of the colour yellow is different in Estonian and in English. In Estonian, the studies show, the colour yellow is only associated with positive things - light

5 https://www.vocabulary.com/dictionary/ (15.05.2020). 
and bright, the sun, happiness and positivity (Käsk 2015: 34). In English yellow also refers to a negative emotion like cowardliness (Kolahdouz 2015: 7). In cases where the translator is not familiar with such information, translating such phrases could prove to be challenging ${ }^{6}$. The culture-specificness is probably the reason why this was one of the metaphors that was most frequently looked up online. Fourteen participants out of 21 found it challenging to provide a translation equivalent without consulting online sources.

\section{(3) Perception metaphor bittersweet memories}

According to Longman Dictionary, 'feelings, memories, or experiences that are bittersweet are happy and sad at the same time ${ }^{77}$. In Estonian, there is no reference to a similar perception metaphor that would be commonly used. The most common translation equivalent in bilingual dictionaries is nukrusevarjundiga 'with a shade of sadness', or poolmorru 'semi bitter' (for chocolate) (Keeleveeb ${ }^{8}$ ). A monolingual dictionary provides different options for referring to 'something that tastes (or smells) sweet and bitter at the same time': kibemagus 'acerb sweet' the same as mõrkjasmagus 'bitterish sweet' or mõrumagus 'bitter sweet', and refers to 'feelings that are pleasant and hurt at the same time' (Sõnaveeb ${ }^{9}$ ).

In the translated texts, many different translation options were provided. The translation strategies used were either preservation of the metaphor with a perception word in Estonian or replacing of the perception metaphor with a metaphor with no perception word.

- The total of 18 participants preserved a perception metaphor in the target text:

\footnotetext{
6 For the analysis of colour metaphor translation, see Kalda, Uusküla (2019). However, the text and the context of the study were different. The previous study included different groups of participants. Namely, professional translators and non-translators (people with C-level proficiency in English, based on Common European Framework of Reference for Languages (CEFR)).

https://doceonline.com/dictionary/ (15.05.2020).

http://www.keeleveeb.ee/ (15.05.2020).

9 https://sonaveeb.ee/ (15.05.2020).
} 


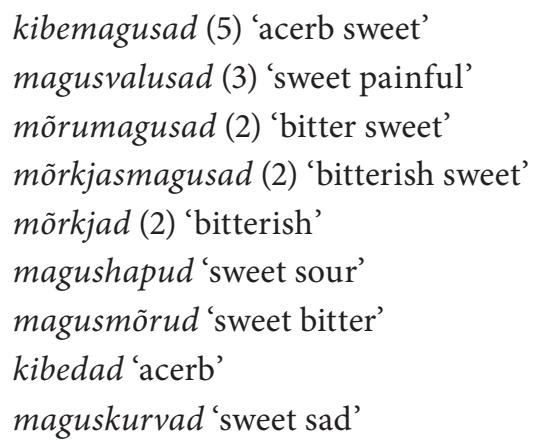

- Three participants replaced the perception metaphor with a metaphor in the translated text:

nukrusevarjundiga 'with a shade of sadness'

kurblõbusad 'sad happy'

mõnevõrra valusad mälestused 'memories that are somewhat painful'

The metaphor bittersweet memories represents also, as Examples (1) and (2), a culture specific perception metaphor. Still, the metaphor did not pose any comprehension difficulties. There were altogether three participants of the total of 21 who consulted online sources during the translation task. Those who did decided to search for synonyms in the target language or translation equivalents aimed at finding a better wording option. We can find evidence of using mõrumagus mälestus in Estonian, but as several participants noted, it is not an habitualized expression and has a strong feeling of Anglicism attached to it. One of the participants emphasised that the meaning of this metaphor is widely known; nevertheless, the attempt to convey it into Estonian and make it sound and feel right for the reader proved to be surprisingly challenging. The interview revealed that the dictionary equivalents do not always prove to be satisfactory as they often sound unnatural and foreign in Estonian. In this particular case the translation strategy chosen was therefore paraphrasing. During one of the interviews another participant pointed out: 'Although I know what bittersweet means, I struggled with finding the best option, and as my expertise is technical translation this a 
type of text I don't have to translate very often, so I was confused... and translating turned out to be more difficult than I assumed.'

\section{(4) Perception metaphor hot debate}

The English metaphor hot debate is used while referring to a 'heated argument/debate/discussion etc. that is full of angry and excited feelings' (Longman Dictionary ${ }^{10}$ ). In Estonian, there is a similar metaphor with a coequal perception word: tuline vaidlus 'hot debate'; 'argument that is hard, sharp, heated, agitated' (Sõnaveeb ${ }^{11}$ ).

All of the participants, with one exception, used the first strategy while translating the metaphor - preserving the perception metaphor in the target text. There was one paraphrasing of the metaphor väga tõsine debatt 'very serious debate'. Perception metaphors in translated texts were:

tuline vaidlus (14) 'hot debate'

kuum vaidlus 'hot debate'

terav debatt (2) 'sharp debate'

terav arutelu (2) 'sharp discussion'

äge vaidlus (1) 'heated debate'

In this context the words tuline and kuum are full synonyms in Estonian. The other option used was terav 'sharp'. There were no comprehension difficulties with this metaphor. Three participants looked up the metaphor online. As explained in the interviews, all online consultations were made to check whether there would be a better synonym available or just to confirm the meaning of the metaphor. This metaphor represents the category of cross-cultural perception metaphors in the study. Such metaphors cause no comprehension problems usually, the digital sources are used to find better wording options and in case no attention is drawn to them specifically, no participant mentioned them during the interviews or presented them as challenging to translate.

\footnotetext{
10 https://doceonline.com/dictionary/ (15.05.2020).

11 https://sonaveeb.ee/ (15.05.2020).
} 


\subsection{ONLINE SOURCES USED DURING THE EXPERIMENT}

The aim of the research was to analyse whether perception metaphors can become a translation challenge. One way to test this is to look at how much assistance the participants took advantage of during the translation task. All of the searches made online during the experiment were counted. There were altogether 460 searches, $313(68 \%)$ of them were related to metaphors, 147 (32\%) were related to other linguistic forms. The digital sources used can be divided into four groups: bilingual dictionaries, monolingual dictionaries, search engines and other web sites. This is illustrated in Figure 1.

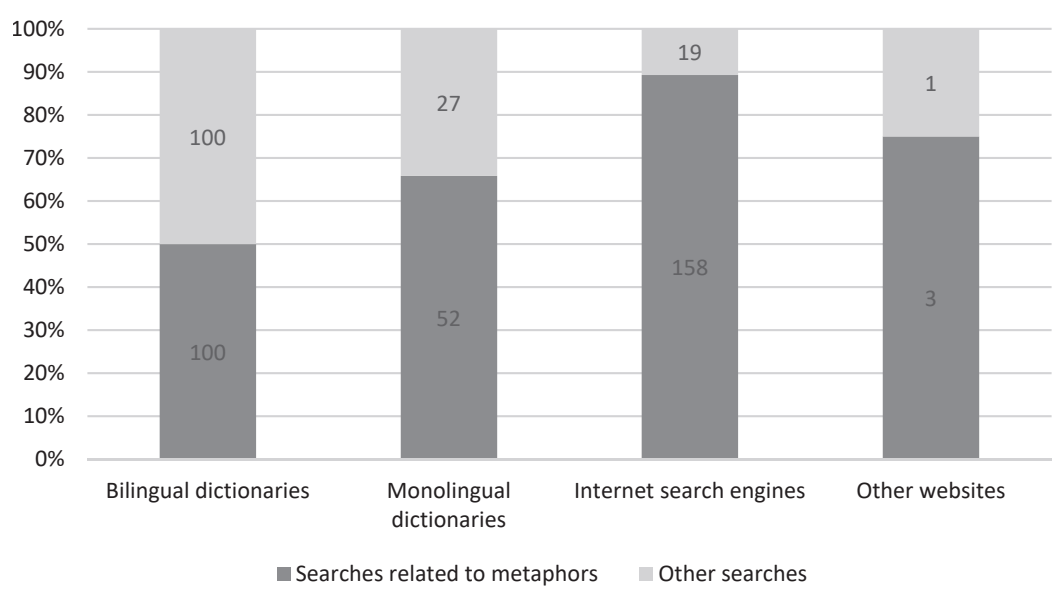

Figure I. The amount and share of consultation of online resources made during the experiment regarding perception metaphors (dark grey) $v$. and other linguistic forms (grey)

For this study it is important to investigate the consulting online sources in more detail. The data in Table 5 suggest that cross-cultural perception metaphors were less challenging to translate than culture specific perception metaphors. For example, black market, juicy scandal and cool friend were not looked up online. On the other hand, more culture specific perception metaphors incurred the need for more consultation before providing a satisfactory translation 
equivalent as Examples (1)-(3) demonstrated. The data on how many searches were made concerning each perception metaphor are depicted in Table 5.

Table 5. The summary of searches made about perception metaphors in the text, per participant, number of searches

\begin{tabular}{|c|c|c|}
\hline & $\begin{array}{l}\text { Number of participants that } \\
\text { searched the metaphor }\end{array}$ & $\begin{array}{l}\text { The amount of searches } \\
\text { made per metaphor }\end{array}$ \\
\hline \multicolumn{3}{|l|}{ Colour metaphors } \\
\hline purple prose & 15 & 29 \\
\hline awash under a brown tide & 14 & 47 \\
\hline yellow belly & 14 & 19 \\
\hline red tape & 11 & 11 \\
\hline white magic & 10 & 20 \\
\hline silver lining & 8 & 13 \\
\hline with flying colours & 8 & 9 \\
\hline catch red-handed & 6 & 6 \\
\hline born with a silver spoon & 4 & 13 \\
\hline white lie & 4 & 5 \\
\hline blue in the face & 3 & 7 \\
\hline dark ages & 3 & 3 \\
\hline out of the blue & 2 & 3 \\
\hline rose-coloured glasses & 1 & 3 \\
\hline silver hair & 1 & 2 \\
\hline golden opportunity & 1 & 1 \\
\hline grey area & 1 & 1 \\
\hline like a red rag to a bull & 1 & 1 \\
\hline true colours & 0 & 0 \\
\hline give a green light & 0 & 0 \\
\hline black market & 0 & 0 \\
\hline \multicolumn{3}{|c|}{ Taste and smell metaphors } \\
\hline salt of the earth & 12 & 18 \\
\hline sour-tempered & 11 & 21 \\
\hline salty language & 7 & 10 \\
\hline soft in the head & 7 & 8 \\
\hline friendship soured & 5 & 7 \\
\hline sharp smell & 4 & 5 \\
\hline bittersweet memories & 3 & 7 \\
\hline
\end{tabular}




\begin{tabular}{|l|c|c|}
\hline & $\begin{array}{c}\text { Number of participants that } \\
\text { searched the metaphor }\end{array}$ & $\begin{array}{c}\text { The amount of searches } \\
\text { made per metaphor }\end{array}$ \\
\hline sweet sixteen & 3 & 4 \\
\hline spicy novel & 3 & 3 \\
\hline soft voice & 2 & 3 \\
\hline sweet dreams & 0 & 0 \\
\hline juicy scandal & 0 & 0 \\
\hline Temperature metaphors & \multicolumn{2}{|l|}{} \\
\hline play it cool & 6 & 7 \\
\hline warm trail & 3 & 5 \\
\hline hot debate & 3 & 3 \\
\hline chilly greeting & 3 & 3 \\
\hline cold in the grave & 2 & 4 \\
\hline hottest war zone & 1 & 6 \\
\hline hot as hell & 1 & 2 \\
\hline out in the cold & 1 & 2 \\
\hline warm support & 1 & 1 \\
\hline cool friend & 0 & 0 \\
\hline
\end{tabular}

It is evident from the data in Table 5 that colour metaphors seem to be more challenging to translate than other perception metaphors. Participants consulted online sources while translating colour metaphors more often than when translating taste, smell or temperature metaphors. This suggests that colour metaphors may be more culture and language specific than for example temperature and taste and smell metaphors.

Several observations can be drawn based on the data from the eye-tracking video recordings on using online consulting during the experiment. The translation behaviour of participants varied. Some participants opened their preferred online dictionary to use during the experiment. In case there was no result given, usually Google was consulted next. Other participants preferred to start their searches from Google and consulted the dictionaries and websites from the results' list. One observation regarding the content on consultation was remarkable. Namely, some participants used websites in the target language as often or even more often than the 
ones in the source language. During the retrospective interviews, they justified such behaviour with the intention of finding a more Estonian-like translation equivalent. Such desire to make the text conform to the target language (domestication strategy according to Venuti 2008) could be observed from the video recordings of three participants. One of them pointed out during the interview that outside the laboratory environment and at home, she would have spent even more time Googling and trying to find better translation equivalents. Data on online consultations (Figure 1) indicate that the use of search engines was evidently more frequent while translating metaphors, and for translating other linguistic forms the participants relied more on bilingual dictionaries. This suggests that for metaphor translation the participants sought assistance from actual language use.

There were two participants who fulfilled the translation task without using online sources. One of them had lived in the United States for 10 years and during the interview she claimed that she experienced no comprehension or translation difficulties, in her opinion due to the experience of living in the source language environment. The data from the translation tasks and the interviews suggest that living in the source language environment has a positive effect on translation. Participants who had such experience mentioned during the interviews that this had been helpful.

\section{Conclusions}

The aim of this study was to analyse translating English perception metaphors into Estonian in a context based empirical study with professional translators. The qualitative analysis of translated texts and translation strategies used and the interviews with the participants of the study confirm the initial hypothesis that perception metaphors seem to be challenging and demanding of more effort to translate, incurring a higher cognitive load than other linguistic forms. Eye-tracking data on consulting online sources during the 
translation task support the conclusion as two thirds of the searches were related to perception metaphors (Figure 1).

Based on the data it is possible to conclude that the more crosscultural the metaphors are, the more similar are the strategies used to translate them. In other words, the participants were more unanimous - the smaller number of different strategies was used and less different translation equivalents were provided (Example (4) perception metaphor hot debate). The opposite holds as well - the more culture specific the metaphor, the more different were the strategies used and the more varied were the translation equivalents given (Examples (1)-(3) in Section 3.1).

One group of metaphors stands out in the study - namely colour metaphors. Based on retrospective interviews and data on consulting online sources, the results of this study suggest that colour metaphors may be more difficult to translate than other perception metaphors as colours convey different connotations in different languages. Both selected examples of purple prose and yellow belly discussed in Section 3.1 support this conclusion.

It must be emphasised that the aim of this research was not to determine whether some strategies used would be better than others, or to distinguish right and wrong translation equivalents. The aim was to describe and analyse the frequency of strategies used within the specific context given and the translation equivalents provided for particular perception metaphors. It could be argued that the results are accidental and related to the specific texts of the current study. However, the results follow a similar pattern to my previous research with a different text and different participants (Kalda 2016). Further research is definitely encouraged in order to investigate the issue making use of other materials and involving different groups of participants. Moreover, future studies should discuss and describe the translation process in more detail, focussing also on the social and professional background of the participants. All attempts to access and understand the 'little black box' of translators would be valuable for translation studies and linguistics. 


\section{REFERENCES}

Collins Dictionary. https://www.collinsdictionary.com/ (15.05.2020).

Ehrensberger-Dow, Maureen 2018. Process research. - A History of Modern Translation Knowledge. Eds. Yves d'Hulst, Yves Gambier. Amsterdam/ Philadelphia: John Benjamins Publishing Company, 293-300.

English Corpora iWeb. https://www.english-corpora.org/iweb/ (15.05.2020). Ervas, Fransesca; Gola, Elisabetta 2017. From a ghost to a sketch: translating metaphors in context. - Reasoning, Metaphor and Science. Eds. Flavia Marcacci, Maria Grazia Rossi. Isonomia: Epistemologica, 9, 41-59.

Glucksberg, Sam 2003. The psycholinguistics of metaphor. - Trends in Cognitive Sciences 7, 2, 92-96.

Hvelplund, Kristian T. 2017. Translators' use of digital resources during translation. - Hermes - Journal of Language and Communication in Business 56, 71-87.

Ibarretxe-Antuaño, Iraide 2019. Perception metaphors in cognitive linguistics. Scope motivation and lexicalisation. - Perception metaphors. Eds. Laura J. Speed, Carolyn O’Meara, Lila San Rogue, Asifa Majid. Amsterdam and Philadelphia: John Benjamins, 1-16.

Johanson, Lars 2002. Contact-induced change in a code-copying framework. - Language Change. The Interplay of Internal, External and Extra-Linguistic Factors. Eds. Mari C. Jones, Edith Esch. Berlin, New York: Mouton de Gruyter, 286-313.

Kalda, Anu 2016. Värvimetafooride tõlkimisest. Empiiriline uurimus inglise-eesti suunal. [Translating Colour Metaphors. Empirical Study of English into Estonian Translation.] MA Thesis. Tallinn: Tallinn University: School of Humanities.

Kalda Anu; Uusküla, Mari 2019. The role of context in translating colour metaphors: an experiment on English into Estonian translation. - Open Linguistics 5, 690-705.

Keeleveeb [Language Web] http://www.keeleveeb.ee/ (15.05.2020).

Kolahdouz, Mandana 2015. A cognitive approach to translating color metaphors in English and Turkish proverbs. Conference Paper. https://www. researchgate.net/publication/284181074. (20.01.2020).

Käsk, Ilona 2015. Värvidega seotud assotsiatsioonid ja emotsioonid ükskeelsetel ja eesti-vene kakskeelsetel. [Colour associations and emotions 
among monolinguals and Russian-Estonian bilinguals]. MA Thesis. Tallinn: Tallinn University: School of Humanities.

Kövecses, Zoltán 2015. Where Metaphors Come From: Reconsidering Context in Metaphor. Oxford: Oxford University Press.

Lakoff, George; Mark Johnson 1980. Metaphors We Live By. Chicago: University of Chicago Press.

Lange, Anne 2008. Tõlkimise aabits. [Translation Primer]. Tallinn: Valgus.

Longman Dictionary. https://www.ldoceonline.com/dictionary (15.05.2020).

Mõttus, Heli 2019. Kujundlike emotsiooniväljendite tõlkimisest inglise-eesti keelesuuna näitel. [Translating figurative emotion language. Empirical study of English into Estonian translation] MA Thesis. Tallinn: Tallinn University: School of Humanities.

Newmark, Peter 1988. A Textbook of Translation. London and New York: Prentice Hall International.

Saar, Maria 2014. Idioomide tõlkimise kognitiivsed eripärad. Tõlkimisprotsessi uurimus hispaania-eesti suunal. [The cognitive aspects of idiom translation. A process study of Spanish into Estonian translation]. MA Thesis. Tallinn: Tallinn University: School of Humanities.

Schäffner, Christina 2004. Metaphor and translation: some implications of a cognitive approach. - Journal of Pragmatics 36, 7, 1253-1269.

Schäffner, Christina; Schuttleworth, Mark 2013. Metaphor in translation. Possibilities for process research. - Target, 25, 1, 93-106.

Sjørup, Annette C. 2008. Metaphor comprehension in translation: methodological issues in a pilot study. - Looking at Eyes. Eye-tracking Studies of Reading and Translation Processing. Eds. Susanne Göpferich, Arnt Lykke Jakobsen, Inger M. Mees. Copenhagen Studies in Language 36, Samfundslitteratur, 53-77.

Sjørup, Annette C. 2013. Cognitive Effort in Metaphor Translation: an eyetracking and key-logging study. PhD Thesis. Fredriksberg: Copenhagen Business School.

Sõnaveeb [Word Web] https://sonaveeb.ee/ (15.05.2020).

Taukar, Marju; Pärn, Reeli; Kaplina, Anna; Ots, Marianne; Pihlakas, Gristel 2018. Suulisest ja kirjalikust tõlkest lõppteksti ja tõlkeprotsessi põhjal. Eesti Rakenduslingvistika Ühingu aastaraamat, 197-214.

Tirkkonen-Condit, Sonja 2001. Metaphors in translation processes and products. - Quadrens. Revista de traducció 6, 11-15. 
Toury, Gideon 1995. Descriptive translation studies and beyond. Amsterdam: John Benjamins.

Urban Dictionary. https://www.urbandictionary.com/ (15.05.2020).

van den Broeck, Raymond 1981. The limits of translatability exemplified by metaphor translation. - Poetics Today 2, 4, 73-87.

Venuti, Lawrence 2008. The Translator's Invisibility: A History of Translation. London, New York: Routledge.

Verschik, Anna 2019. English-Estonian code-copying in blogs: combining a contact linguistic and cognitive approach. - Cognitive Contact Linguistics. Eds. Eline Zenner, Ad Backus, Esme Winter-Froemel. BerlinBoston: De Gruyter Mouton, 51-80.

Vinay, Jean-Paul; Darbelnet, Jean 1995. Comparative Stylistics of French and English: A methodology for translation. Translated from French by J. C. Sager and, J. M. Hamel. Amsterdam, Philadelphia: John Benjamins Publishing Company.

Vocabulary.com. https://www.vocabulary.com/dictionary/ (15.05.2020). 


\section{RESÜMEE}

\section{TAJUMETAFOORIDE TÕLKIMISEST. PROTSESSIPÕHINE LÄHENEMINE}

Artikli eesmärk on kirjeldada ja analüüsida inglise tajumetafooride tõlkimist eesti keelde. Selleks, et selgitada, milliseid tõlkestrateegiaid tõlkijad kasutavad, viidi läbi empiiriline kontekstipõhine tõlkekatse. Hüpoteesi kohaselt võivad tekstis sisalduvad tajumetafoorid tõlkijale tõlkeprotsessis väljakutseks kujuneda ja võrreldes teiste keelenditega suuremat kognitiivset koormust põhjustada. Lisaks tõlkestrateegiate kasutamise analüüsile keskendus artikkel internetiallikate kasutamisele. Eeldati, et tajumetafoorid tingivad vajaduse abimaterjale kasutada sagedamini kui teised tõlketekstis esinevad keelendid.

Tõlkekatseks koostati iWebi korpuse põhjal neli tõlketeksti, milles oli kokku 43 tajumetafoori. Neist 21 värvimetafoori, 12 lõhna- või maitsemetafoori ja 10 temperatuurimetafoori. Valitud metafoorid sisaldasid kultuurispetsiifilisi metafoore, mis on omased ja leksikaliseerunud lähtekultuuris (nt yellow-bellied person) ja kultuuriüleseid tajumetafoore, mis on kasutusel nii lähte- kui sihtkultuuris (nt black market, hot as hell). Andmed koguti Mirametrix pilgujälgija ja klahvivajutusprogrammi Translog II abil. Oluliseks uurimismaterjaliks olid katsejärgsed retrospektiivsed intervjuud. Katses osales 21 vabatahtlikku professionaalset tõlkijat.

Analüüsiks kohandati varasemalt värvimetafooride tõlkimise kirjeldamiseks kasutatud tõlkestrateegiate klassifikatsiooni (Kalda 2016). Tõlketekstide analüüs näitas, et kaks kolmandikku metafooridest säilis ka tõlkes. Kognitiivse koormuse analüüsimiseks kasutati lisaks katsejärgsetele intervjuudele ka veebipõhiste abimaterjalide kasutamise analüüsi. Kõigist 460 internetis tehtud päringust 313 (68\%) olid seotud tajumetafooridega, 147 (32\%) teiste keelenditega.

Analüüsi põhjal võib väita, et tajumetafooride tõlkimine toob kaasa suurema kognitiivse koormuse kui teiste keelendite tõlkimine. Lisaks sellele ilmnes, et mida kultuuriülesemad on tajumetafoorid, seda sarnasemalt neid tõlgitakse ja seda väiksem on erinevate tõlkevastete arv. 
Mida kultuurispetsiifilisemad on tajumetafoorid, seda rohkem erinevaid tõlkestrateegiaid kasutatakse ja seda erinevamaid tõlkevasteid tõlkijad kasutavad.

Andmete ja intervjuude põhjal tulevad eriti esile värvimetafoorid. Nende tõlkimisel kasutati rohkem internetiallikate abi ja neid märgiti katsejärgsetes intervjuudes tihti kui keerukamaid osi tõlketekstides. Selle põhjal on alust väita, et värvimetafoorid on kultuurispetsiifilisemad ja neid võib olla keerulisem tõlkida kui lõhna-, maitse- ja temperatuurimetafoore.

Võtmesõnad: metafooride tõlkimine, kultuuriülesed metafoorid, kultuurispetsiifilised metafoorid, tõlkestrateegiad, tõlkimisprotsess, veebiotsingud, kognitiivne lingvistika, eesti keel, inglise keel

Anu Kalda is a PhD student in Linguistics at Tallinn University. She uses the methods of cognitive and psycholinguistics to investigate how English perception metaphors are translated into Estonian. In addition to cultural and linguistic influence on understanding and translating metaphors, she also analyses the translation process.

anukalda@tlu.ee 